\title{
Are Chinese consumers at risk due to exposure to metals in crayfish?
} A bioaccessibility-adjusted probabilistic risk assessment

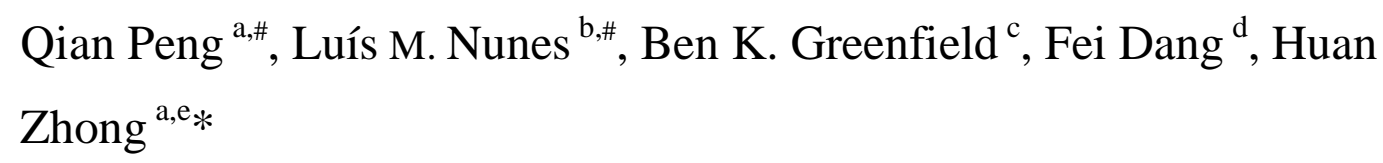

${ }^{a}$ Nanjing University, School of Environment, State Key Laboratory of Pollution Control and Resource Reuse, Nanjing, Jiangsu Province, People's Republic of China

${ }^{\mathrm{b}}$ University of Algarve, Civil Engineering Research and Innovation for Sustainability Center, Faro, Portugal

${ }^{\mathrm{c}}$ Environmental Health Sciences Division, School of Public Health, University of California, Berkeley, USA

${ }^{\mathrm{d}}$ State Key Laboratory of Soil Environment and Pollution Remediation, Institute of Soil Science, Chinese Academy of Sciences, Nanjing, Jiangsu Province, People's Republic of China

${ }^{\mathrm{e}}$ Environmental and Life Sciences Program, Trent University, Peterborough, Ontario, Canada

Abbreviations: HQ, hazard quotient; HI, hazard index; ILTR, increased lifetime risk; FAO, Food and Agriculture Organization; NBSC, National Bureau of Statistics of China; USITC, United States International Trade Commission; MLYR, middle and lower reaches of the Yangtze River; ICP-MS, inductively coupled plasma-mass spectroscopy; CRM, certified reference material; USEPA, United States Environmental Protection Agency; RfD, reference dose; EDI, estimated daily intake; CSF, cancer slope factor; IR, ingestion rate; BW, body weight; ED, exposure duration; EF, exposure frequency; AT, averaging time; NCRPM, National Council on Radiation Protection and Measurements; MCS, Monte Carlo Simulation; pd, probability distribution; USFDA, United States Food and Drug Administration.

\# These authors contributed equally.

* Corresponding author at: School of Environment, Nanjing University, State Key Laboratory of Pollution Control and Resource Reuse, 163 Xian Lin Da Dao, Nanjing, 210023, China. Tel.:+86 25 89680136. E-mail address: zhonghuan@ nju.edu.cn 


\section{Abstract:}

Freshwater crayfish, the world's third largest crustacean species, has been reported to accumulate high levels of metals, while the current knowledge of potential risk associated with crayfish consumption lags behind that of finfish. We provide the first estimate of human health risk associated with crayfish (Procambarus clarkii) consumption in China, the world's largest producer and consumer of crayfish. We performed Monte Carlo Simulation on a standard risk model parameterized with local data on metal concentrations, bioaccessibility $(\varphi)$, crayfish consumption rate, and consumer body mass. Bioaccessibility of metals in crayfish was found to be variable (68-95\%) and metal-specific, suggesting a potential influence of metal bioaccessibility on effective metal intake. However, sensitivity analysis suggested risk of metals via crayfish consumption was predominantly explained by consumption rate (explaining $>92 \%$ of total risk estimate variability), rather than metals concentration, bioaccessibility, or body mass. Mean metal concentrations ( $\mathrm{As}, \mathrm{Cd}, \mathrm{Cu}, \mathrm{Ni}, \mathrm{Pb}, \mathrm{Se}$ and Zn) in surveyed crayfish samples from 12 provinces in China conformed to national safety standards. However, risk calculation of $\varphi$-modified hazard quotient (HQ) and hazard index (HI) suggested that crayfish metals may pose a health risk for very high rate consumers, with a $\mathrm{HI}$ of over 24 for the highest rate consumers. Additionally, the $\varphi$-modified increased lifetime risk (ILTR) for carcinogenic effects due to the presence of As was above the acceptable level $\left(10^{-5}\right)$ for both the median (ILTR $\left.=2.5 \times 10^{-5}\right)$ and $90^{\text {th }}$ percentile $\left(\right.$ ILTR $=1.8 \times 10^{-4}$ ), highlighting the relatively high risk of As in crayfish. Our results suggest a need to consider crayfish when assessing human dietary exposure to metals and associated health risks, especially for high crayfish-consuming populations, such as in China, USA and Sweden.

Keywords: Metal, Crayfish, Human Health Risk Assessment, Uncertainty, Sensitivity 


\section{Introduction}

Freshwater crayfish (Decapoda: Parastacidae and Astacidae) are a significant worldwide aquatic food (FAO, 2014; NBSC, 2013), with a long history of human consumption (Patoka et al., 2014). In some European countries, long-standing cultural traditions are still linked with crayfish consumption, especially in Scandinavia (Taugbøl and Skurdal, 1999). In the USA, crayfish used as food is popular in Wisconsin, Minnesota, Arkansas, Mississippi, and Texas, and especially popular in Louisiana, where more than 90 percent of US crayfish are processed (Holdich, 1993; USITC, 2003). In China, crayfish have been widely used as food since the 1980s (Mu et al., 2007).

Crayfish are also widely reported to accumulate high concentrations of metals (Alcorlo et al., 2006; Anderson et al., 1997a, b; Kouba et al., 2010; Kuklina et al., 2014). Due to their omnivory as well as necrophagia and life spans up to six years, crayfish bioaccumulate multiple toxins and heavy metals in their shells and flesh. Hazards associated with crayfish consumption have been reported, including Haff disease (Xie et al., 2010; Zhang et al., 2012), human paragonimiasis (Lane et al., 2009), Vibrio infections (Anda et al., 2001; Bean et al., 1998; Kay et al., 2012), intoxication by natural or man-made toxins (Vasconcelos, 1999; Vasconcelos et al., 2001), and effects resulting from exposure to organic contaminants (Gewurtz et al., 2000; Levengood and Schaeffer, 2011; Schilderman et al., 1999). Multiple studies have demonstrated heavy metal contamination in crayfish in the USA (Mason et al., 2000; Besser et al., 2007; Hothem et al., 2007; Moss et al., 2010), Italy (Bellante et al., 2015; Bruno et al., 2006), Spain (Devesa et al., 2002; Alcorlo et al., 2006; Vioque-Fernandez et al., 2007) and China (Huang, 2009; Wu et al., 2010; Peng et al., 2015). However, most of the previous studies were based on localized sampling, 
especially in contaminated areas. Levels of metal contamination in crayfish intended for human consumption at regional or national scales have rarely been reported.

China is the world's largest producer and consumer of crayfish (FAO, 2014; Mu et al., 2007; NBSC, 2013). Of the more than 500,000 tons of reported crayfish production and consumption annually worldwide (McClain and Romaire, 2007), China alone is responsible for 529,000 tons per year, exporting about 26,000 tons, mainly into the USA and Europe (Mu et al., 2007; NBSC, 2013; Schuler et al., 2000). The majority of crayfish production is used for human consumption within China $(\mathrm{Mu}$ et al., 2007; Qiu et al., 2012; Yue et al., 2009). Dietary metal exposure has also been shown to pose health risk to consumers in China. In particular, arsenic (As) exposure from consumption of rice and other foods poses incremental lifetime cancer risk increases to 1 to 2 per 1,000 Chinese individuals (Li et al., 2011). Given the above mentioned hazards and wide population exposure, the health risk of crayfish consumption in China warrants study. Among the few studies focused on health risk due to metal exposure via crayfish consumption (Schuler et al., 2000; Wu et al., 2010), a small-scale survey in Shanghai City showed that lead $(\mathrm{Pb})$ intake due to crayfish consumption could pose risk to human health (Wu et al., 2010). However, data are limited at regional or national scales in China on metal concentrations and dietary bioavailability in crayfish, as well as dietary consumption rates.

When assessing metal exposure via diet, total metal burden often provides a conservative (i.e., high) estimate of exposure due to the fact that only a fraction of metal is bioavailable (Oomen et al., 2002; Versantvoort et al., 2005). In vitro bioaccessibility tests, validated against in vivo studies ( $\mathrm{Li}$ et al., 2014a; Li et al., 2014b; Schroder et al., 2004), provide a reliable method to assess metal bioavailability, which aids in dietary exposure and risk assessment (Amiard et al., 2008). 
We report on the first large-scale assessment of health risk due to heavy metals in crayfish in China. Our study includes regions throughout China, but focuses on the main region of crayfish consumption, the middle and lower reaches of the Yangtze River delta area. Cooked red swamp crayfish (Procambarus clarkii) were collected from restaurants in 23 cities in China, and determined for metal concentrations (As, $\mathrm{Cd}, \mathrm{Cu}, \mathrm{Ni}, \mathrm{Pb}, \mathrm{Se}$ and $\mathrm{Zn}$ ). Effective metal intake (i.e., metal bioaccessibility) was estimated using an in vitro digestion model and considered in a probabilistic risk calculation. Risk indices include increased lifetime cancer risk (ILTR) for As, and the hazard quotient (HQ) for all examined metals. Finally, sensitivity analysis was performed to compare the relative importance of metal concentration, bioaccessibility, ingestion rate, and consumer body weight for risk via crayfish consumption.

\section{Materials and methods}

\subsection{Crayfish sampling}

We obtained 210 red swamp crayfish (Procambarus clarkii) samples from 23 cities (12 provinces, Supplemental Information Figure S1), in which crayfish consumption has been frequently reported. Samples were obtained in September, 2012, during the peak season of crayfish consumption (i.e., June to September, Peng et al., 2015). Among the selected cities, 15 were located in the middle and lower reaches of the Yangtze River (MLYR), China's main crayfish producing and consuming area (Mu et al., 2007), and 8 were located in other regions of the country (Figure S1). A single site (restaurant) was sampled for crayfish in each city, except Nanjing, for which three separate restaurants were sampled.

Exposure was assessed as consumed, rather than from contamination of the raw commodity. Therefore, all samples were of cooked crayfish intended for human 
consumption, obtained from local restaurants. Crayfish were cooked by either stewing or frying. Cooking methods had no significant effect on metal (except for $\mathrm{Zn}$ ) bioaccessibility (nested ANOVA, site nested within cooking, $p>0.05$; Supplemental Information Table S1), and thus the effects of cooking methods on the risk of metals were not considered in this study. We did not distinguish farm-raised versus wild-caught crayfish in this study. However, the majority of crayfish consumed in China are farm-raised (Mu et al., 2007; Yue et al., 2009). All samples were vacuum-packed, stored on ice, and transported to the lab within 3 days. After tail length determination $(5.4 \pm 0.8 \mathrm{~cm})$, tail muscle (edible part of crayfish) was dissected, weighed $(3.0 \pm 1.1 \mathrm{~g})$, rinsed with ultrapure water and freeze-dried. Samples were ball-milled to a fine powder and stored at $-20^{\circ} \mathrm{C}$ until further analysis.

\subsection{Determining metal concentrations in crayfish tail muscle}

Subsamples of crayfish tail muscle were digested in concentrated trace metal grade nitric acid $\left(\mathrm{HNO}_{3}\right)$, and then analyzed for $\mathrm{As}, \mathrm{Cd}, \mathrm{Cu}, \mathrm{Ni}, \mathrm{Pb}$, Se and $\mathrm{Zn}$ by inductively coupled plasma-mass spectroscopy (ICP-MS, Perkin Elmer/NexION300). The instrument detection limits were $0.08,0.06,0.43,0.07,0.48,0.50$ and $0.63 \mathrm{ng} \mathrm{L}^{-1}$ for $\mathrm{Cd}, \mathrm{Cu}, \mathrm{Ni}, \mathrm{Pb}, \mathrm{As}, \mathrm{Se}$ and $\mathrm{Zn}$, respectively. Quality control for digestion and ICP-MS analysis included blanks, certified reference material (CRM; scallop tissue, GBW10024), and duplicate measurement (RSD < 10\%). Instrumental quality control included calibration checks and running a standard after every 30 samples. Additionally, internal standards were used to correct the sensitivity drift and matrix effects (Long and Martin, 1989): Bi, Ge, In and Sc were spiked into the digested samples $\left(1 \mu \mathrm{g} \mathrm{L}^{-1}\right)$ before analysis. CRM (3 replicates) was digested and analyzed with each batch of samples. The recoveries (mean $\pm \mathrm{SD}$ ) of $\mathrm{As}, \mathrm{Cd}, \mathrm{Cu}, \mathrm{Ni}, \mathrm{Pb}, \mathrm{Se}$ and 
Zn in the CRM were $98 \pm 8 \%, 97 \pm 6 \%, 99 \pm 11 \%, 103 \pm 11 \%, 96 \pm 15 \%, 102 \pm$ $10 \%$ and $97 \pm 11 \%$, respectively.

\subsection{Bioaccessibility of metals in crayfish tail muscle}

Metal bioaccessibility was measured in 24 samples from 8 restaurants in MLYR, including Suqian, Suzhou, Anqing, Hangzhou, Anji, and Xinyang cities, and 2 restaurants in Nanjing City (see Supplemental Information Table S2). In this study, freeze-dried tissues were used for assessing metal bioaccessibility. Our preliminary experiments (using 10 crayfish individuals from 5 sampling sites) indicated that freeze-drying had insignificant effects on either concentration or bioaccessibility of metals. Dietary metal bioaccessibility was estimated by the in vitro digestion model developed by Versantvoort et al. (2005), simulating the digestion processes in the human mouth, stomach and small intestine. Briefly, digestion juices, including saliva, gastric juice, duodenal juice and bile juice, were prepared artificially and heated to 37 $\pm 2{ }^{\circ} \mathrm{C}$ before use (details described in Supplemental Information Table S3). Crayfish subsamples were mixed with saliva $(\mathrm{pH}=6.8)$ and incubated for $5 \mathrm{~min}$, followed by addition of gastric juice $(\mathrm{pH}=1.3)$ for $2 \mathrm{~h}($ mixed $\mathrm{pH}=2-3)$, and then, simultaneous administration of duodenal juice $(\mathrm{pH}=8.1)$, bile $(\mathrm{pH}=8.2)$ and $1 \mathrm{M} \mathrm{NaHCO}_{3}$ solution for another $2 \mathrm{~h}$. The final $\mathrm{pH}$ in the mixture was 6.5-7. The sample-to-fluid ratio was 1:95 $\left(\mathrm{g} \mathrm{mL}^{-1}\right)$ at a volume ratio of 3 saliva:6 gastric juice:6 duodenal juice:3 bile: $1 \mathrm{NaHCO}_{3}$ for the digestion juice (Oomen et al., 2003). A sample-to-fluid ratio of 1:95 instead of 1:98 (Oomen et al., 2003) was used in this study to facilitate calculating solution volumes. However, minor changes in sample-to-fluid ratios have insignificant effects on quantified metal bioaccessibility (Hamel et al., 1998; Oomen et al., 2003). Mixing was conducted at $55 \mathrm{rpm}$ at $37^{\circ} \mathrm{C}$, followed by centrifugation 
$(1640 \times g, 5 \mathrm{~min})$ to separate the supernatants and pellets. Scallop tissue (GBW10024) was used as a CRM for quality control.

Both supernatants and residues were digested in concentrated $\mathrm{HNO}_{3}$ and analyzed for metals by ICP-MS as described in Section 2.2. Bioaccessibility (\% extractability) was defined as $100 \times$ (metal in supernatant)/(metal in tail muscle before extraction). The recoveries of metal extraction, i.e., $100 \times$ (metal in supernatant + metal remaining in the residue)/(metal in tail muscle before extraction), exhibited ranges of $89-112 \%, 91-109 \%, 86-107 \%, 93-112 \%, 91-107 \%$ and $93-113 \%$ for As, $\mathrm{Cd}, \mathrm{Cu}, \mathrm{Ni}, \mathrm{Se}$ and $\mathrm{Zn}$ respectively.

\subsection{Ingestion rates}

We based rates of crayfish ingestion by humans on a previously published questionnaire survey performed in Nanjing City, a representative city in MLYR (Peng et al., 2015). Survey answers were validated by asking some logically identical questions with different wording and cross-checking for inconsistencies among the answers (Iarossi, 2006). Description of the survey method and study population may be found in Peng et al. (2015). Ingestion rates for survey participants were calculated based on the product of (1) the amount of crayfish consumed per meal (g/meal), and (2) the frequency of crayfish consumption during the peak season (meal/week). Ingestion rates during the peak season were averaged and reported as daily intakes. The sampled population included both consumers and non-consumers (ca. 11\%) of crayfish.

\subsection{Health risk assessment and uncertainty analysis}

We evaluated human health risks of exposure to metals in crayfish tail muscle, 
employing the methodology used for determining exposure levels to environmental contaminants that are likely to be associated with adverse health effects (USEPA, 1989). We employed the reference dose method to evaluate hazard of noncarcinogenic effects. In this method, estimated daily intake is compared to a reference dose (RfD), with an acceptably low lifetime risk of deleterious effect, considered protective to broader population groups, including sensitive populations (USEPA, 1989, 2015a, b). We estimated hazard quotients (HQ; unitless) to evaluate hazard of non-carcinogenic effects; HQ are obtained by dividing the estimated mean daily intake for a specific metal $i\left(\mathrm{EDI}_{i} ; \mathrm{mg} / \mathrm{kg} / \mathrm{d}\right)$ by the $\mathrm{RfD}(\mathrm{mg} / \mathrm{kg} / \mathrm{d})$ :

$$
H Q_{\mathrm{i}}=E D I_{i} / R f D_{i}
$$

A hazard index is then obtained by summing the HQ for the different metals:

$$
H I=\sum_{i} H Q_{i}
$$

For As, being a carcinogenic metal, the increased lifetime risk of cancer (ILTR) is also estimated, corresponding to the increased probability of developing cancer due to the quantified exposure:

$$
I L T R_{j}=E D I_{j} \times C S F_{j}
$$

$C S F_{j}$ stands for cancer slope factor, which is a plausible upper-bound estimate of the probability of a response per unit intake of a chemical over a lifetime (USEPA, 1989). The acceptable carcinogenic risk is usually considered to be between 1 per million and 1 per hundred thousand (Hunter and Fewtrell, 2001). The RfD and CSF parameters in the risk models (1) through (3) were set at values provided by USEPA (2015a, b) and ATDSR (2007), compiled in Table 1. <Table 1> Estimated daily intake (EDI) from crayfish consumption was obtained by multiplying daily consumption rate by corresponding metal concentrations in the 
foodstuff, adjusted by the bioaccessibility $\left(\varphi_{i}\right)$, considered equal regardless of the cooking method, as justified above:

$$
E D I_{i}=\left(C_{i} \times \varphi_{i} \times I R \times E D \times E F\right) /(B W \times A T)
$$

where $C_{i}=$ concentration of metal $i$ in crayfish $(\mathrm{mg} / \mathrm{kg}) ; I R=$ ingestion rate $(\mathrm{kg} / \mathrm{d})$; $B W=$ body weight $(\mathrm{kg}) ; E D=$ exposure duration (years); $E F=$ exposure frequency (days/year); and $A T=$ averaging time, set at 75 years $\times 365$ days/year.

Quantitative uncertainty analysis was employed to obtain a population estimation of the range of risks encountered (NCRPM, 1996). Sensitivity analysis was further performed to identify the parameters which had the strongest impact on the model outcomes (Hamby, 1994), being therefore the best candidates for further scientific assessment, as well as the best indicators for decision making and public communication.

Monte Carlo Simulation (MCS) was used to perform quantitative sensitivity and uncertainty analysis (Metropolis and Ulam, 1949; Thompson and Graham, 1996), employing as inputs probability distributions based on empirical data. Specifically, the propagation of uncertainty through the risk equations (1) through (4) was simulated. Statistical distributions were derived for human body weight, ingestion rate, crayfish metal concentration, and bioavailability. The non-parametric Kolmogorov-Smirnov test $(\alpha=0.01)$ was used to compare each empirical statistical distribution with the sample probability distribution $(p d)$. Only Normal, Lognormal and Weibull distributions were tested, as they are the most frequently used in exposure and risk characterization studies (Apt, 1976; Caldwell et al., 2008). Body weight (BW) per age and sex was separated in yearly classes from birth until age 20, then every ten years until age 80 . Above 80, a single age class was considered (Li et al., 2011). The $p d$ for $\mathrm{BW}$ was obtained by attributing to each age class the calculated $\mathrm{BW}$ and 
percentage of the national population. The remaining variables were obtained specifically for the study and therefore their $p d$ were obtained directly from the sampled data. MCS were performed in Crystal Ball@ (Oracle, Redwood City, CA, USA), using Latin hypercube sampling. Individual parameter contributions to variance in the outcomes (noncancer hazard index and increased lifetime cancer risk) were estimated by taking the square of the spearman rank correlation coefficient between each input variable and each outcome, and normalizing to $100 \%$. The maximum number of trials that Crystal Ball ran before stopping the simulation was set at 500,000 .

\section{Results and discussion}

\subsection{Metal concentrations in crayfish}

Observed $\mathrm{As}, \mathrm{Cd}, \mathrm{Cu}, \mathrm{Ni}, \mathrm{Pb}, \mathrm{Se}$ and $\mathrm{Zn}$ concentrations (wet weight, mean $\pm \mathrm{SD}$ ) were $253.3 \pm 142.4 \mu \mathrm{g} / \mathrm{kg}, 29.8 \pm 39.2 \mu \mathrm{g} / \mathrm{kg}, 9.2 \pm 5.8 \mathrm{mg} / \mathrm{kg}, 171.2 \pm 141.2 \mu \mathrm{g} / \mathrm{kg}$ $23.3 \pm 29.5 \mu \mathrm{g} / \mathrm{kg}, 294.4 \pm 154.1 \mu \mathrm{g} / \mathrm{kg}$ and $20.1 \pm 6.3 \mathrm{mg} / \mathrm{kg}$, respectively $(\mathrm{N}=210$, tail muscle samples). Concentrations varied widely among cities and large variations in metal concentrations were observed for each metal (Table 2). It has been widely reported that effects of cooking on metal concentrations in fish and shellfish are minimal (Perelló et al., 2008; Kalogeropoulos et al., 2012), and thus the reported crayfish metal levels should not be significantly affected by cooking. Metal concentrations for $\mathrm{As}, \mathrm{Cd}$ and $\mathrm{Pb}$ in all samples were below Chinese national safety standards (GB2762-2012; SAPRC, 2012); $\mathrm{Cu}, \mathrm{Ni}, \mathrm{Se}$ and $\mathrm{Zn}$ are not listed in the national standards. Crayfish metal concentrations found in our study were generally within the ranges of those reported in Chinese freshwater fish (Cheung et al., 2008), although As concentrations $(253 \pm 142 \mu \mathrm{g} / \mathrm{kg})$ were higher than the freshwater fish 
from the MLYR region (17 $\pm 9 \mu \mathrm{g} / \mathrm{kg}$ for 469 fish samples, Yi et al., 2011). Kouba et al. (2011) summarized global literature on $\mathrm{Cu}, \mathrm{Zn}, \mathrm{Ni}, \mathrm{Cd}$, and $\mathrm{Pb}$ in crayfish tail muscle on a dry weight basis. We converted concentration ranges in our study from wet to dry weight assuming $75 \%$ moisture content (Peng et al., 2015), to facilitate comparison to this range of concentrations observed globally. Concentration ranges were comparable for $\mathrm{Cu}$, which were $7.2-157.6 \mathrm{mg} / \mathrm{kg}$ dry weight in our study versus 2.3-110.8 mg/kg in Kouba et al. (2011). Concentration ranges were also comparable for $\mathrm{Ni}(0.06-3.8$ our study versus $0.3-3.8 \mathrm{mg} / \mathrm{kg}$ globally) and $\mathrm{Zn}$ (40.4-196 versus 4.0-95.6 mg/kg). However, our study concentration ranges were generally lower than global concentration ranges for $\mathrm{Cd}(0.003-1.71$ versus $0.015-4.3 \mathrm{mg} / \mathrm{kg})$ and $\mathrm{Pb}$ $(<0.001-1.01$ versus $0.015-11.9 \mathrm{mg} / \mathrm{kg})$. The relatively low concentrations of $\mathrm{Cd}$ and $\mathrm{Pb}$ may be explained by the fact that crayfish is mostly farm-raised in China (Mu et al., 2007; Yue et al., 2009). In particular, aquaculture management practices in China, including short cultivation duration and rapid growth rates (Mu et al., 2007), may result in growth dilution. This could be partly responsible for the relatively low metal levels (Zhang et al., 2010). <Table 2>

Compared to total As in our study crayfish (mean $=253 \mu \mathrm{g} / \mathrm{kg}$ wet; $1012 \mu \mathrm{g} / \mathrm{kg}$ dry weight), As concentrations in crayfish varied widely among regions sampled globally. Muscle As concentrations were lower in crayfish muscle obtained from two remote freshwater streams in Maryland, USA (60 and $120 \mu \mathrm{g} / \mathrm{kg}$ dry weight; data extracted from Figure 9 in Mason et al., 2000) and from Pacifastacus leniusculus and Procambarus clarkii collected from California, USA streams with historic gold mining influence (240 to $680 \mu \mathrm{g} / \mathrm{kg}$ dry weight; Hothem et al., 2007). In contrast, total As was higher in freshwater crayfish (Cherax destructor Clark) muscle from western Victoria, Australia sites with historic coal or gold mining (1700 to $2600 \mu \mathrm{g} / \mathrm{kg}$ dry 
weight; Williams et al., 2009) and whole crayfish (P. clarkii) obtained from a creek below a severe breach of a mine tailings reservoir in Doñana National Park, Andalusia, Spain (1600 to $8500 \mu \mathrm{g} / \mathrm{kg}$ dry weight; Devesa et al., 2002). Concentrations were also generally higher in crayfish $(P$. clarkii) muscle from two agriculturally impacted lakes in Sicily, Italy (median $=1820$; range $<200$ to $4030 \mu \mathrm{g} / \mathrm{kg}$ dry weight; Bellante et al., 2015).

\subsection{Metal bioaccessibility in crayfish}

Across all measured samples, mean bioaccessibility (\% extractability) of the examined trace elements in crayfish was $77.6 \% \pm 16.5,78.7 \% \pm 6.1,82.6 \% \pm 12.6$, $89.2 \% \pm 17.1,92.5 \% \pm 2.9$, and $95.4 \% \pm 6.2$ for $\mathrm{Zn}, \mathrm{Cd}, \mathrm{Se}, \mathrm{Ni}, \mathrm{Cu}$ and $\mathrm{As}$, respectively (Figure 1; Supplemental Information Table S2). Lead bioaccessibility was not determined because extracted $\mathrm{Pb}$ levels were too low to be precisely measured. <Figure 1>

Metal bioaccessibility in cooked aquatic food has been reported in only a few studies (He et al., 2010; He and Wang, 2013; Houlbreque et al., 2011; Metian et al., 2009). Bioaccessibility of metals in this study were generally in agreement with those reported in steamed seafood tissue (47.8\%-85.9\% for clams, He and Wang, 2013; $52.2 \%-84.3 \%$ for seabass, He et al., 2010), but higher than those in cooked mussels (34\%-63\%, Metian et al., 2009). Cooking was reported to decrease metal bioaccessibility in mussels (Houlbreque et al., 2011), gastropods (Amiard et al., 2008), and fish (He et al., 2010). In most previous surveys, metal bioaccessibility was quantified in uncooked shellfish, which may not be realistic for human consumption of cooked shellfish. The explicit inclusion of bioaccessibility of cooked samples in exposure estimates should reduce the uncertainty and bias in risk assessment. All 
bioaccessibility data for a specific metal was treated as coming from a single population, and the propagation of this uncertainty was assessed through the MCS.

\subsection{Ingestion rates}

Peng et al. (2015, Table 4) estimated consumption of crayfish in China and in the middle and lower reaches of the Yangtze River (MLYR). According to these estimates, crayfish consumption outside MLYR was only about $4 \%$ of the total national consumption. This observation is consistent with previous studies (Qiao and Jiang, 2010; Shen, 2010; Wang, 2010), and reports that MLYR is the main producing and consuming area of crayfish in China and globally (FAO, 2014; Mu et al., 2007; NBSC, 2013). In MLYR, crayfish consumption rates could reach more than 100 metric tons per day per city (Mu et al., 2007) during the peak season (i.e., June to September; Peng et al., 2015). Therefore, crayfish consumption in MLYR would represent the majority of human exposure in China, as well as a conservative (i.e., high) estimate of individual exposure rates for crayfish consumers in China. For these reasons, we estimate crayfish ingestion rate (IR) using survey data from Nanjing (Peng et al., 2015), as a proxy of a typical city in MLYR.

The ingestion rate (IR) in the Nanjing survey data (Peng et al., 2015) is highly skewed and varies dramatically among individuals (Figure 2). The skewness is illustrated by median IR ( $8.8 \mathrm{~g} / \mathrm{d} /$ person $)$, well below mean $(27.6 \mathrm{~g} / \mathrm{d} /$ person $)$ and $90^{\text {th }}$ percentile (93.3 g/d/person). <Figure 2>

To accommodate such variability in the estimate, the IR frequency distribution was introduced in the probabilistic modelling of risk as a custom $p d$. Specifically, ingestion rate was modeled by drawing repeated samples from the individual survey results. Given the strong seasonal variation in consumption and resulting intermittent 
exposure, the calculation of the risk from intermittent exposures was calculated as the sum of short-term exposures, by using the averaging procedure included in equation (1), with EF equal to $120 \mathrm{~d}$ /year. Using data reported in Table 4 and Table 5 of Peng et al. (2015), the mean consumption rate from the Nanjing survey in the peak season ( $27.6 \mathrm{~g} / \mathrm{d} /$ person) is approximately 6 times of that of Hubei Province ( $4.7 \mathrm{~g} / \mathrm{d} /$ person) and 14 times of the MLYR as a whole $(2.0 \mathrm{~g} / \mathrm{d} /$ person $)$, the latter values obtained from China population annual fishery statistics (NBSC, 2013; Peng et al., 2015). The discrepancy likely results from the fact that most crayfish consumption occurs during the 120 day harvesting season, when the survey was conducted. Thus, the Nanjing survey results employed in our probabilistic risk calculations represent a conservative estimate of exposure during the peak harvesting season.

\subsection{Health risk due to exposure to metals by consuming crayfish in MLYR}

As discussed above (Section 3.3) and documented in previous studies (Mu et al., 2007; Peng et al., 2015; Qiao and Jiang, 2010; Shen, 2010; Wang, 2010), crayfish consumption in MLYR represents the highest potential health hazard for crayfish consumption in China. Therefore, the following risk calculation and discussion focuses on MLYR, which could be interpreted as a conservative estimate of risk associated with crayfish consumption in China. The estimated exposure for MLYR residents was expressed by probability distributions derived from data presented in Table 3. Correlations between model parameters were weak as indicated by correlation coefficients always lower than $0.45(p<0.05)$, indicating that parameter dependencies have little impact on the overall risk results (USEPA, 2001). <Table 3>

Sensitivity analysis results indicated that greater than $92 \%$ of the variation in calculated risk was due to ingestion rate, with a small portion $(<7 \%)$ attributable to 
arsenic concentrations. All other parameters (including body weight, bioaccessibility, and other metals concentrations) explained $<0.5 \%$ individually and $<1.5 \%$ in combination (Table 4). The unimportance of bioaccessibility $(<0.1 \%)$ is somewhat surprising, and likely stems from high bioaccessibility coefficients and a limited range. In light of this low sensitivity, any uncertainty in bioaccessibility would be expected to have a trivial effect on risk estimates. The overwhelming importance of crayfish consumption rate stems from the wide range in consumption rates among individuals sampled. High variability in seafood consumption rates has been well documented across individuals and populations, and as a result local and subpopulation-specific consumption rate estimates are useful prior to generating seafood consumption guidance (e.g., Allen et al., 1996; Sechena et al., 2003; SFEI and CDHS, 2000; USEPA, 2000; USEPA, 2011). Our results, in combination with these findings, suggest that consumption rate estimates would be the primary monitoring priority for obtaining better estimates of risk due to dietary metals exposure from crayfish. <Table $4>$.

MCS-derived median $\left(50^{\text {th }}\right.$ percentile $)$ and P90 $\left(90^{\text {th }}\right.$ percentile $)$ HQ values were well below 1.0, indicating low health hazard per metal (Table 1). The highest HQ was found for As $(\mathrm{P} 90=0.40)$, followed by $\mathrm{Cu}(\mathrm{P} 90=0.11)$. $\mathrm{P} 90$ for the combined $\mathrm{HI}$ was 0.57, indicating that the highly exposed individuals are exposed to intakes close to the maximum admissible. Although less than 1.0, these HI values may still be important for crayfish consumers because crayfish is not the only significant source of metal exposure (e.g., Li et al., 2011). In the consumption survey (Peng et al., 2015), 0.5\% (i.e., 3 out of 501 respondents) of the surveyed individuals (high consumption population) reported consuming over $466 \mathrm{~g} / \mathrm{d}$ of crayfish muscle, resulting in a HI of over 24 (see range in Table 1). Although high-end estimates of consumption rates are 
likely subject to greater measurement uncertainty (Sechena et al., 2003), our results do suggest that some individuals in Nanjing City (and MLYR generally) may be exposed to metals at hazardous levels from crayfish consumption.

The relative contribution of each metal to our estimated HI differed from that for freshwater fish of the MLYR (Yi et al., 2011). For our MCS P90 results, arsenic contributed $70 \%$ to total $\mathrm{HI}$, followed by $\mathrm{Cu}(18 \%), \mathrm{Zn} \mathrm{(5 \% )}$ and Se (4\%), with a trivial $(<0.001 \%)$ contribution due to $\mathrm{Pb}$ (Table 1). In contrast, for freshwater fish, $\mathrm{Pb}$ explained 36.5\% of total HI, Cd 30.2\%, Cu 11.4\%, and $\mathrm{Zn} \mathrm{6.3 \%} \mathrm{(Yi} \mathrm{et} \mathrm{al.,} \mathrm{2011).}$ These differences result from higher As concentrations in crayfish than in freshwater fish in China (discussed above). The moderately high contribution of $\mathrm{Cu}$ to dietary exposure risk, together with prior studies (e.g., Wang et al., 2001), indicates the importance of considering $\mathrm{Cu}$ contamination in aquatic food and associated food safety issues in China.

The median and $90^{\text {th }}$ percentile of ILTR from As were estimated to be 2.5 per 100,000 and 18 per 100,000 , respectively. Both are greater than typical acceptable risk thresholds (i.e., above 1 per 100,000; USEPA, 2000). A previous study calculated a total ILTR due to As intake in the Chinese diet as 177 per 100,000 (Li et al., 2011). Employing this rate, for typical versus high rate consumers in the MLYR, crayfish could contribute to approximately $1.4-9.6 \%$ of the total risk due to dietary As exposure. Of course these results do not address the combined risks from additional carcinogenic chemicals that may be present in seafood (e.g., halogenated organic compounds; USEPA, 2000), nor the potential for underestimation of risk due to intermittent exposures (Felter et al., 2011; Halmes et al., 2000).

It should also be noted that variations in As speciation in crayfish (e.g., mainly as dimethylarsinate, Williams et al., 2009) could play a role in As bioavailability, 
toxicity, and resulting risk. Our results demonstrated that As bioaccessibility was generally high across samples (i.e., $95.4 \pm 6.2 \%$, Supplemental Information Table S2), suggesting that potential variations in As speciation in these samples may play a minor role in As bioaccessibility. However, because we did not determine As species, and inorganic arsenic is more toxic than organic arsenic (ATSDR 2007), our risk interpretations are conservative, and As speciation in crayfish prepared for human consumption warrants further investigation.

\section{Conclusion}

This study provided the first large-scale survey and probabilistic risk assessment of metals in crayfish consumed in China, the world's largest producer and consumer of crayfish. Metal concentrations in crayfish were generally low to moderate, with concentrations of $\mathrm{Cd}$ and $\mathrm{Pb}$ on the low end of observed global concentrations. $\mathrm{An}$ exception was As, which exhibited higher concentrations than finfish in China (Yi et al., 2011) and crayfish from USA streams (Mason et al., 2000; Hothem et al., 2007). Metal bioaccessibility in crayfish, determined by an in vitro digestion model, were a priori, and based on previous studies, considered to provide a more realistic risk assessment. Results found variable bioaccessibility among different metals, which was considered in our risk calculations. Risk models showed, however, little sensitivity to bioaccessibility coefficients, likely due to high values and limited ranges. The calculated median and $90^{\text {th }}$ percentile value of HQ and HI (bioaccessibility-modified) suggested low health hazard due to most heavy metals in crayfish, indicating that contamination by $\mathrm{Cu}, \mathrm{Cd}, \mathrm{Pb}, \mathrm{Ni}, \mathrm{Se}$, and $\mathrm{Zn}$ in crayfish are unlikely to pose a health hazard for noncarcinogenic effects to the general population in China. 
The risk for carcinogenic effects due to the presence of As was above the acceptable level of 1 per 100,000 , for both the median $\left(\right.$ ILTR $=2.5 \times 10^{-5}$ ) and $90^{\text {th }}$ percentile $\left(\right.$ ILTR $\left.=1.8 \times 10^{-4}\right)$. Consequently, As contamination in crayfish may pose a health risk for high rate consumers in regions of China where crayfish consumption is popular (e.g., MLYR). Considering the already high reported human dietary exposure to As in China, particularly due to rice consumption ( $\mathrm{Li}$ et al., 2011), we may expect that supplementary sources of As intake for high rate crayfish consumers may pose a meaningful risk increase. There are two caveats to this interpretation. First, we did not determine the proportions of the more toxic inorganic As species, which have been quite variable in the few studies where they were measured in crayfish (Devesa et al., 2002; Williams et al., 2009). Second, risk calculations in this study were mainly based on data from MLYR, which is the main area of crayfish consumption in China. Thus, conclusions about risk drawn in this study are conservative and should be extrapolated with caution to other areas in China, with generally lower crayfish consumption.

Results from the stochastic simulation emphasized the dominant role of consumption rate in controlling risk of metals via crayfish consumption in China. For instance, risk calculation demonstrated that crayfish metals may pose a health risk for high rate consumers (e.g., in MLYR), highlighting the importance of considering ingestion rates when assessing risk of crayfish metals. Therefore, guidance for crayfish consumption in China (especially in MLYR cities) and other world regions with high crayfish consumption may help reduce potential hazard, especially for high consumption individuals. To mitigate the potential risk associated with eating crayfish, and further delineate exposure for high rate consumers and sensitive populations, additional consumption surveys for crayfish and other freshwater fish in China are also warranted. For example, this survey about consumption rates was conducted in 
urban areas, which may differ from rural populations. Probabilistic risk assessments may also be warranted for crayfish consumers in other crayfish consuming regions such as Scandinavian countries and the southeastern United States, especially for As which varies widely among regions. Finally, in addition to metals, contamination of crayfish by organic contaminants may pose an added risk to crayfish consumers. These issues may affect the overall risk associated with crayfish consumption, warranting further investigation in future studies.

\section{Acknowledgements}

The authors thank Dr. Douglas Evans for his kind help and two anonymous reviewers for providing very constructive comments to the manuscript. Financial support was provided to HZ by the National Natural Science Foundation of China (41273087). LN was supported by European Union Marie Curie Actions, Grant FP People 2010 "IRSES Electroacross" and BG by the SAGE-IGERT Fellowship (US National Science Foundation). 


\section{References}

Alcorlo P, Otero M, Crehuet M, Baltanas A, Montes C. The use of the red swamp crayfish (Procambarus clarkii, Girard) as indicator of the bioavailability of heavy metals in environmental monitoring in the River Guadiamar (SW, Spain). Sci Total Environ 2006; 366:380-90.

Allen MJ, Velez PV, Diehl DW, McFadden SE, Kelsh M. Demographic variability in seafood consumption rates among recreational anglers of Santa Monica Bay, California, in 1991-1992. Fish B-Noaa 1996; 94:597-610.

Amiard JC, Amiard-Triquet C, Charbonnier L, Mesnil A, Rainbow PS, Wang WX. Bioaccessibility of essential and non-essential metals in commercial shellfish from Western Europe and Asia. Food Chem Toxicol 2008; 46:2010-22.

Anda P, Del Pozo JS, Garcia JMD, Escudero R, Pena FJG, Velasco MCL, Sellek RE, Chillaron MRJ, Serrano LPS, Navarro JFM. Waterborne outbreak of tularemia associated with crayfish fishing. Emerg Infect Dis 2001; 7:575-82.

Anderson MB, Preslan JE, Jolibois L, Bollinger JE, George WJ. Bioaccumulation of lead nitrate in red swamp crayfish (Procambarus clarkii). J Hazard Mater 1997a; $54: 15-29$.

Anderson MB, Reddy P, Preslan JE, Fingerman M, Bollinger J, Jolibois L, Maheshwarudu G, George WJ. Metal accumulation in crayfish, Procambarus clarkii, exposed to a petroleum-contaminated bayou in Louisiana. Ecotox Environ Safe 1997b; 37:267-72.

Apt KE. Applicability of the Weibull distribution function to atmospheric radioactivity data. Atmos Environ 1976; 10(9):777-81.

ATSDR. Toxicological profile for Arsenic. Atlanta, GA: Agency for Toxic Substances and Disease Registry. United States Department of Health and 
Human Services; 2007. http://www.atsdr.cdc.gov/toxprofiles/index.asp [accessed 2 December 2015]

Bean NH, Maloney EK, Potter ME, Korazemo P, Ray B, Taylor JP, Seigler S, Snowden J. Crayfish: A newly recognized vehicle for vibrio infections. Epidemiol Infect 1998; 121:269-73.

Bellante A, Maccarone V, Buscaino G, Buffa G, Filiciotto F, Traina A, Del Core M, Mazzola S, Sprovieri M. Trace element concentrations in red swamp crayfish (Procambarus clarkii) and surface sediments in Lake Preola and Gorghi Tondi natural reserve, SW Sicily. Environ Monit Assess 2015; 187:404.

Besser JM, Brumbaugh WG, May TW, Schmitt CJ. Biomonitoring of lead, zinc, and cadmium in streams draining lead-mining and non-mining areas, southeast Missouri, USA. Environ Monit Assess 2007; 129:227-41.

Bruno G, Volpe MG, De Luise G, Paolucci M. Detection of heavy metals in farmed Cherax destructor. B Fr Pêche Piscic 2006; 380-381:1341-9.

Buchet JP, Lison D, Ruggeri M, Foa V, Elia G. Assessment of exposure to inorganic arsenic, a human carcinogen, due to the consumption of seafood. Arch Toxicol 1996; 70:773-8.

Caldwell DJ, Mastrocco F, Hutchinson TH, Laenge R, Heijerick D, Janssen C, Anderson PD, Sumpter JP. Derivation of an aquatic predicted no-effect concentration for the synthetic hormone, 17 alpha-ethinyl estradiol. Environ Sci Technol 2008; 42(19):7046-54.

Cheung KC, Leung HM, Wong MH. Metal concentrations of common freshwater and marine fish from the Pearl River Delta, South China. Arch Environ Con Tox $2008 ; 54: 705-15$.

Devesa, V, Suner, MA, Lai, VWM, Granchinho, SCR, Martinez, JM, Velez, D, 
Cullen, WR, Montoro, R. Determination of arsenic species in a freshwater crustacean Procambarus clarkii. Appl Organomet Chem 2002; 16:123-32.

FAO. FAO Yearbook: Fishery and Aquaculture Statistics. Rome, Italy: Food and Agriculture Organization; 2014.

Felter SP, Conolly RB, Bercu JP, Bolger PM, Boobis AR, Bos PMJ, Carthew P, Doerrer NG, Goodman JI, Harrouk WA, Kirkland DJ, Lau SS, Llewellyn GC, Preston RJ, Schoeny R, Schnatter AR, Tritscher A, Van Velsen F, Williams GM. A proposed framework for assessing risk from less-than-lifetime exposures to carcinogens. Crit Rev Toxicol 2011; 41:507-44.

Gewurtz SB, Lazar R, Haffner GD. Comparison of polycyclic aromatic hydrocarbon and polychlorinated biphenyl dynamics in benthic invertebrates of Lake Erie, USA. Environ Toxicol Chem 2000; 19:2943-50.

Halmes NC, Roberts SM, Tolson JK, Portier CJ. Reevaluating cancer risk estimates for short-term exposure scenarios. Toxicol Sci 2000; 58:32-42.

Hamby D. A review of techniques for parameter sensitivity analysis of environmental models. Environ Monit Assess 1994; 32:135-54.

Hamel SC, Buckley B, Lioy PJ. Bioaccessibility of metals in soils for different liquid to solid ratios in synthetic gastric fluid. Environ Sci Technol 1998; 32:358-62

He M, Ke CH, Wang WX. Effects of cooking and subcellular distribution on the bioaccessibility of trace elements in two marine fish species. J Arg Food Chem $2010 ; 58: 3517-23$.

He M, Wang WX. Bioaccessibility of 12 trace elements in marine molluscs. Food Chem Toxicol 2013; 55:627-36.

Holdich DM. A review of astaciculture: freshwater crayfish farming. Aquat Living Resour 1993; 6(04):307-17. 
Hothem RL, Bergen DR, Bauer ML, Crayon JJ, Meckstroth AM. Mercury and trace elements in crayfish from Northern California. B Environ Contam Tox 2007; $79: 628-32$.

Houlbreque F, Herve-Fernandez P, Teyssie JL, Oberhaensli F, Boisson F, Jeffree R. Cooking makes cadmium contained in Chilean mussels less bioaccessible to humans. Food Chem 2011; 126:917-21.

Huang X. The contamination evaluation of the five heavy metals enriched in Procambarus clarkii and the water in Anhui. Academic Dissertation. Anhui Agricultural University; 2009. [In Chinese].

Hunter P, Fewtrell L. Acceptable risk. In: Fewtrell L, Bartram J (Eds.): World Health Organization. Water Quality: Guidelines, Standards and Health. London, England: IWA Publishing; 2001; 207-27.

Iarossi G. The power of survey design: A user's guide for managing surveys, interpreting results, and influencing respondents. Washington, DC: The World Bank; 2006.

Kalogeropoulos N, Karavoltsos S, Sakellari A, Avramidou S, Dassenakis M, Scoullos M. Heavy metals in raw, fried and grilled Mediterranean finfish and shellfish. Food Chem Toxicol 2012; 50(10):3702-8.

Kay MK, Cartwright EJ, MacEachern D, McCullough J, Barzilay E, Mintz E, Duchin JS, MacDonald K, Turnsek M, Tarr C. Vibrio mimicus infection associated with crayfish consumption, Spokane, Washington, 2010. J Food Protect 2012; 75:762-4.

Kouba A, Buric M, Kozak P. Bioaccumulation and effects of heavy metals in crayfish: A review. Water Air Soil Poll 2010; 211:5-16.

Kuklina I, Kouba A, Buric M, Horka I, Duris Z, Kozak P. Accumulation of heavy 
metals in crayfish and fish from selected Czech reservoirs. BioMed Res Int 2014; 306103, 9 pages. http://dx.doi.org/10.1155/2014/306103 [accessed 2 December 2015]

Lane MA, Barsanti MC, Santos CA, Yeung M, Lubner SJ, Weil GJ. Human paragonimiasis in North America following ingestion of raw crayfish. Clin Infect Dis 2009; 49:E55-61.

Levengood JM, Schaeffer DJ. Polycyclic aromatic hydrocarbons in fish and crayfish from the calumet region of Southwestern Lake Michigan. Ecotoxicology 2011; 20:1411-21.

Li G, Sun GX, Williams PN, Nunes L, Zhu YG. Inorganic arsenic in Chinese food and its cancer risk. Environ Int 2011; 37:1219-25.

Li HB, Cui XY, Li K, Li J, Juhasz AL, Ma, LQ. Assessment of in vitro lead bioaccessibility in house dust and its relationship to in vivo lead relative bioavailability. Environ Sci Technol 2014a; 48:8548-55.

Li HB, Li J, Juhasz AL, Ma LQ. Correlation of in vivo relative bioavailability to in vitro bioaccessibility for arsenic in household dust from China and its implication for human exposure assessment. Environ Sci Technol 2014b; 48:13652-9.

Long SE, Martin TD. Determination of Trace Elements in Waters and Wastes by Inductively Coupled Plasma-Mass Spectrometry: Test Method 200.8[M]. US Environmental Protection Agency, Office of Research and Development, Environmental Monitoring and Systems Laboratory; 1989.

Mason, RP, Laporte JM, Andres S. Factors controlling the bioaccumulation of mercury, methylmercury, arsenic, selenium, and cadmium by freshwater invertebrates and fish. Arch Environ Con Tox 2000; 38:283-97. 
McClain WR, Romaire RP. Procambarus clarkii (Girard, 1852). Cultured Aquatic Species Information Program. In FAO Fisheries and Aquaculture Department [Online]. Rome, Italy: Food and Agriculture Organization; 2007. http://www.fao.org/fishery/culturedspecies/Procambarus_clarkii/en\#tcNA00D9 [accessed 2 December 2015]

Metian M, Charbonnier L, Oberhaensli F, Bustamante P, Jeffree R, Amiard JC, Warnau M. Assessment of metal, metalloid, and radionuclide bioaccessibility from mussels to human consumers, using centrifugation and simulated digestion methods coupled with radiotracer techniques. Ecotox Environ Safe 2009; 72:1499-502.

Metropolis N, Ulam S. The monte carlo method. J Am Stat Assoc 1949; 44(247):335-41.

Moss JC, Hardaway CJ, Richert JC, Sneddon J. Determination of cadmium copper, iron, nickel, lead and zinc in crawfish [Procambrus clarkii] by inductively coupled plasma optical emission spectrometry: A study over the 2009 season in Southwest Louisiana. Microchem J 2010; 95:5-10.

Mu F, Cheng Y, Wu X. Distribution and industrial development of crayfish in the world. J Shanghai Fish Univ 2007; 16(1):64-72 [In Chinese].

NBSC. China Statistical Yearbook. National Bureau of Statistics of China; 2013. http://www.stats.gov.cn/tjsj/ndsj/2013/indexeh.htm [accessed 2 December 2015]

NCRPM. A guide for uncertainty analysis in dose and risk assessment related to environmental contamination. Bethesda, MD, USA: National Council on Radiation Protection and Measurements; 1996.

Oomen AG, Hack A, Minekus M, Zeijdner E, Cornelis C, Schoeters G, Verstraete W, Van de Wiele T, Wragg J, Rompelberg CJM, Sips A, Van Wijnen JH. 

Comparison of five in vitro digestion models to study the bioaccessibility of soil contaminants. Environ Sci Technol 2002; 36:3326-34.

Oomen AG, Rompelberg CJM, Bruil MA, Dobbe CJG, Pereboom D, Sips A. Development of an in vitro digestion model for estimating the bioaccessibility of soil contaminants. Arch Environ Con Tox 2003; 44:281-7.

Patoka J, Fisakova MN, Kalous L, Skrdla P, Kuca M. Earliest evidence for human consumption of crayfish. Crustaceana 2014; 87:1578-85.

Peng Q, Greenfield BK, Dang F, Zhong H. Human exposure to methylmercury from crayfish (Procambarus clarkii) in China. Environ Geochem Hlth 2015; 1-13.

Perelló G, Martí-Cid R, Llobet JM, Domingo JL. Effects of various cooking processes on the concentrations of arsenic, cadmium, mercury, and lead in foods. J Agr Food Chem 2008; 56(23):11262-9.

Qiao G, Jiang S. Report on development of the crayfish industry in Jiangsu Province. Fish Guide to be Rich 2010; 13:24-6. [In Chinese].

Qiu Y, Strid A, Bignert A, Zhu Z, Zhao J, Athanasiadou M, Bergman Å. Chlorinated and brominated organic contaminants in fish from Shanghai markets: A case study of human exposure. Chemosphere (2012); 89(4):458-66.

Richert JC, Sneddon J. Determination of inorganics and organics in crawfish. Appl Spectrosc Rev 2008; 43:49-65.

Schilderman P, Moonen EJC, Maas LM, Welle I, Kleinjans JCS. Use of crayfish in biomonitoring studies of environmental pollution of the river Meuse. Ecotox Environ Safe 1999; 44:241-52.

Schroder L, Basta NT, Casteel SW, Evans TJ, Payton ME, Si J. Validation of the in vitro gastrointestinal (IVG) method to estimate relative bioavailable lead in contaminated soils. J Environ Qual 2004; 33:513-21. 
Schuler LJ, Howell JP, Heagler MG. Mercury concentrations in Louisiana and Chinese crayfish. B Environ Contam Tox 2000; 64:27-32.

Sechena R, Liao S, Lorenzana R, Nakano C, Polissar N, Fenske R. Asian American and Pacific Islander seafood consumption — a community-based study in King County, Washington. J Expo Anal Environ Epidemiol 2003; 13:256-66.

SFEI and CDHS. San Francisco Bay Seafood Consumption Study. Richmond, CA: San Francisco Estuary Institute and California Department of Health Services; 2000.

Shen Y. Report on the development of the crayfish industry in Jiangsu Province. China Fish 2010; 6:14-6. [In Chinese].

SAPRC. Maximum Levels of Contaminants in Foods. GB2762-2012. Beijing, China: Standardization Administration of the People's Republic of China; 2012.

Tan S, Zhao L, Guan P. Research on the acute effect of 5 kinds of fishery drugs on crayfish Procambarus clarkii. J Anhui Agr Sci 2010; 38(33):18852-4. [In Chinese].

Taugbøl T, Skurdal J. The future of native crayfish in Europe: How to make the best of a bad situation? p. 271-9 In: Gheraardi F, Holdich DM (Eds.): Crayfish in Europe as alien species: How to make the best of a bad situation; 1999.

Thompson KM, Graham JD. Going beyond the single number: Using probabilistic risk assessment to improve risk management. Hum Ecol Risk Assess 1996; 2:1008-34.

USEPA. Risk Assessment Guidance for Superfund Volume I Human Health Evaluation Manual (Part A) Interim Final. Washington, DC: United States Environmental Protection Agency; 1989.

USEPA. Guidance for assessing chemical contaminant data for use in fish advisories. 
Volume 1. Fish sampling and analysis. 3rd edition. Washington, DC: United States Environmental Protection Agency; 2000.

USEPA. Risk Assessment Guidance for Superfund: Volume III-Part A, Process for Conducting Probabilistic Risk Assessment. Washington, DC: United States Environmental Protection Agency; 2001.

USEPA. Exposure Factors Handbook 2011 Edition. Washington, DC: National Center for Environmental Assessment, United States Environmental Protection Agency; 2011.

USEPA. Regional Screening Table [Online]. Washington, DC: United States Environmental Protection Agency; 2015a. http://www2.epa.gov/risk/regional-screening-table [accessed 2 December 2015]

USEPA. Integrated Risk Information System (IRIS) 2015b. Washington, DC: United States Environmental Protection Agency; 2015b. http://www.epa.gov/iris/ [accessed 2 December 2015]

USFDA. Guidance Documents for Trace Elements in Seafood. Washington, DC: Center for Food Safety and Applied Nutrition, United States Food and Drug Administration; 1993.

USITC. Crawfish tail meat from China. Investigation No. 731-TA-752 (Review). Publication 3614. Washington, DC: United States International Trade Commission; 2003.

Vasconcelos V, Oliveira S, Teles FO. Impact of a toxic and a non-toxic strain of Microcystis aeruginosa on the crayfish Procambarus clarkii. Toxicon 2001; 39(10):1461-70.

Vasconcelos VM. Cyanobacterial toxins in Portugal: Effects on aquatic animals and risk for human health. Braz J Med Biol Res 1999; 32:249-54. 
Versantvoort CHM, Oomen AG, Van de Kamp E, Rompelberg CJM, Sips A. Applicability of an in vitro digestion model in assessing the bioaccessibility of mycotoxins from food. Food Chem Toxicol 2005; 43:31-40.

Vioque-Fernandez A, Alves de Almeida E, Ballesteros J, Garcia-Barrera T, Gomez-Ariza JL, Lopez-Barea J. Doñana National Park survey using crayfish (Procambarus clarkii) as bioindicator: Esterase inhibition and pollutant levels. Toxicol Lett 2007; 168:260-8.

Wang, WX, Yang Y, Guo X, He M, Guo F, Ke C. Copper and zinc contamination in oysters: subcellular distribution and detoxification. Environ Toxicol Chem 2011; 30(8):1767-74.

Wang Z. Report on the development of crayfish industry in Hubei Province. China Fish 2010; 10:14-5. [In Chinese].

Williams G, West JM, Koch I, Reimer KJ, Snow ET. Arsenic speciation in the freshwater crayfish, Cherax destructor Clark. Sci Total Environ $2009 ; 407(8): 2650-8$.

Wu C, Liu H, Fang Y, Lu D, Xing Z, Yuan W, Duan S, Qin L. Survey on the content and intake of lead and cadmium in crayfish from market in Shanghai. J Environ Occup Med 2010; 27(11):650-6. [In Chinese].

Xie W, Chen K, Zhu X, Nie X, Zheng G, Pan D, Wang S. Evaluation on heavy metal contents in water and fishes collected from the waterway in the Pearl River Delta, South China. J Agro- Environ Sci 2010; 29:1917-23. [In Chinese].

Yi Y, Yang Z, Zhang S. Ecological risk assessment of heavy metals in sediment and human health risk assessment of heavy metals in fishes in the middle and lower reaches of the Yangtze River Basin. Environ Pollut 2011; 159:2575-85.

Yue CF, Wang TT, Wang YF, Peng Y. Effect of combined photoperiod, water calcium 

concentration and $\mathrm{pH}$ on survival, growth, and moulting of juvenile crayfish (Procambarus clarkii) cultured under laboratory conditions. Aquac Res 2009; 40(11):1243-50.

750

Zhang B, Yang G, Yu X, Mao H, Xing C, Liu J. Haff disease after eating crayfish in 751 East China. Internal Med 2012; 51:487-9.

752

Zhang H, Feng X, Larssen T, Qiu G, Vogt RD. In inland China, rice, rather than fish, 753 is the major pathway for methylmercury exposure. Environ Health Persp 2010;

754 118(9): 1183-8.

755 
Table 1. Estimated oral reference doses (RfD, $\mathrm{mg} / \mathrm{kg} / \mathrm{d})$ and cancer slope factor (CSF, $(\mathrm{mg} / \mathrm{kg} / \mathrm{d})^{-1}$ ) for metals (USEPA, 2015a, b), daily intake for crayfish consuming populations in China (EDI, mg/kg/d), hazard quotient (HQ, unitless), hazard index (HI, unitless), and increased lifetime cancer risk (ILTR, unitless).

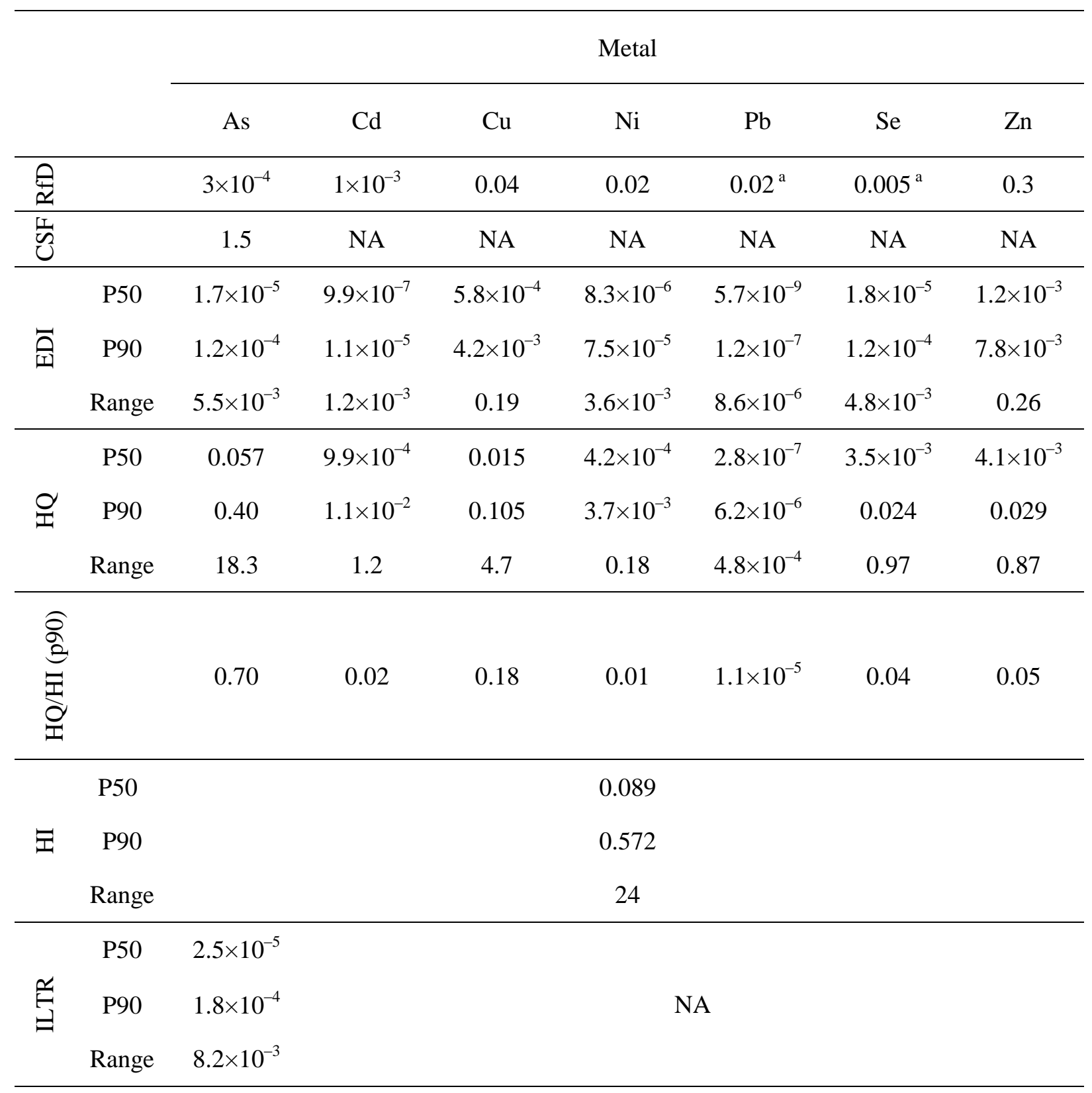

NA: not applicable.

${ }^{\text {a }}$ The value corresponds to the Minimal Risk Level. 
Table 2. Trace element concentrations (wet weight) in tail muscle of cooked crayfish (Procambarus clarkii) sampled in restaurants in China. Mean \pm standard deviation (SD).

\begin{tabular}{|c|c|c|c|c|c|c|c|c|c|}
\hline & & Sample & As & $\mathrm{Cd}$ & $\mathrm{Cu}$ & $\mathrm{Ni}$ & $\mathrm{Pb}$ & $\mathrm{Se}$ & $\mathrm{Zn}$ \\
\hline City & Province & size & $\mu \mathrm{g} / \mathrm{kg}$ & $\mu \mathrm{g} / \mathrm{kg}$ & $\mathrm{mg} / \mathrm{kg}$ & $\mu \mathrm{g} / \mathrm{kg}$ & $\mu \mathrm{g} / \mathrm{kg}$ & $\mu \mathrm{g} / \mathrm{kg}$ & $\mathrm{mg} / \mathrm{kg}$ \\
\hline Nanjing & Jiangsu & 26 & $259.8 \pm 121.0$ & $43.8 \pm 35.0$ & $11.1 \pm 8.2$ & $211.1 \pm 89.9$ & $18.0 \pm 8.4$ & $254.6 \pm 82.8$ & $18.2 \pm 3.4$ \\
\hline Suqian & Jiangsu & 9 & $450.3 \pm 125.5$ & $46.8 \pm 32.6$ & $16.1 \pm 7.0$ & $274.1 \pm 209.5$ & $44.5 \pm 49.5$ & $173.1 \pm 83.7$ & $17.0 \pm 2.2$ \\
\hline Lianyungang & Jiangsu & 9 & $174.7 \pm 39.3$ & $44.8 \pm 58.4$ & $13.1 \pm 5.0$ & $199.3 \pm 123.3$ & $16.0 \pm 10.1$ & $169.7 \pm 61.8$ & $14.6 \pm 2.8$ \\
\hline Suzhou & Jiangsu & 9 & $237.1 \pm 93.3$ & $41.1 \pm 19.9$ & $6.1 \pm 1.6$ & $74.5 \pm 39.3$ & $21.7 \pm 16.1$ & $229.7 \pm 94.8$ & $16.4 \pm 1.6$ \\
\hline Huai'an & Jiangsu & 9 & $300.5 \pm 112.6$ & $30.0 \pm 37.0$ & $8.7 \pm 3.8$ & $109.1 \pm 35.8$ & $31.3 \pm 20.9$ & $167.3 \pm 51.7$ & $16.1 \pm 4.6$ \\
\hline Yangzhou $^{\mathrm{a}}$ & Jiangsu & 2 & $237.9 \pm 13.0$ & $20.2 \pm 0.1$ & $3.7 \pm 1.7$ & $98.8 \pm 18.0$ & $\mathrm{ND}^{\mathrm{b}}$ & $159.2 \pm 31.2$ & $23.2 \pm 0.4$ \\
\hline Yiyang & Hunan & 9 & $211.2 \pm 42.1$ & $30.0 \pm 1.7$ & $6.0 \pm 1.4$ & $62.5 \pm 69.2$ & $1.7 \pm 3.8$ & $614.2 \pm 80.4$ & $22.1 \pm 2.1$ \\
\hline Bengbu & Anhui & 9 & $147.4 \pm 45.3$ & $25.3 \pm 0.7$ & $7.9 \pm 2.4$ & $64.5 \pm 14.3$ & $12.3 \pm 19.4$ & $236.8 \pm 93.3$ & $23.5 \pm 2.8$ \\
\hline Suzhou & Anhui & 9 & $128.8 \pm 17.9$ & $24.7 \pm 3.3$ & $14.2 \pm 5.5$ & $272.0 \pm 148.4$ & $49.1 \pm 27.8$ & $234.9 \pm 36.0$ & $21.3 \pm 2.0$ \\
\hline
\end{tabular}




\begin{tabular}{|c|c|c|c|c|c|c|c|c|c|}
\hline Chuzhou & Anhui & 9 & $274.6 \pm 67.3$ & $33.8 \pm 4.3$ & $11.4 \pm 5.8$ & $268.5 \pm 45.9$ & $16.4 \pm 25.5$ & $328.4 \pm 112.2$ & $30.6 \pm 3.5$ \\
\hline Anqing $^{a}$ & Anhui & 6 & $95.5 \pm 29.4$ & $45.5 \pm 49.4$ & $16.7 \pm 8.7$ & $101.4 \pm 35.3$ & $19.6 \pm 30.9$ & $205.7 \pm 31.4$ & $26.0 \pm 4.0$ \\
\hline Wuhan & Hubei & 9 & $412.2 \pm 155.3$ & $38.2 \pm 2.0$ & $5.5 \pm 1.3$ & $337.3 \pm 72.8$ & $\mathrm{ND}^{\mathrm{b}}$ & $222.1 \pm 41.1$ & $36.9 \pm 5.4$ \\
\hline Huang gang & Hubei & 9 & $331.2 \pm 105.2$ & $37.0 \pm 11.3$ & $12.7 \pm 5.4$ & $181.6 \pm 56.2$ & $3.8 \pm 11.3$ & $215.3 \pm 34.8$ & $28.1 \pm 2.7$ \\
\hline Hangzhou & Zhejiang & 9 & $215.2 \pm 55.5$ & $2.8 \pm 1.7$ & $6.1 \pm 2.4$ & $76.5 \pm 54.3$ & $74.8 \pm 74.0$ & $331.7 \pm 150.6$ & $17.3 \pm 2.3$ \\
\hline Anji & Zhejiang & 9 & $105.1 \pm 16.3$ & $2.8 \pm 0.4$ & $5.7 \pm 1.8$ & $65.2 \pm 16.0$ & $30.4 \pm 6.1$ & $408.6 \pm 93.3$ & $17.4 \pm 0.8$ \\
\hline Zigong $^{\text {a }}$ & Sichuang & 5 & $168.8 \pm 83.7$ & $38.1 \pm 7.0$ & $3.5 \pm 1.2$ & $73.8 \pm 43.3$ & $41.1 \pm 62.3$ & $249.5 \pm 106.5$ & $27.5 \pm 1.7$ \\
\hline Anyang & Henan & 9 & $552.4 \pm 186.8$ & $16.9 \pm 10.3$ & $8.7 \pm 3.2$ & $164.8 \pm 49.5$ & $41.1 \pm 65.1$ & $203.9 \pm 62.3$ & $13.6 \pm 1.4$ \\
\hline Xinyang & Henan & 9 & $113.0 \pm 37.3$ & $1.2 \pm 0.4$ & $6.2 \pm 2.4$ & $71.9 \pm 17.1$ & $19.8 \pm 7.3$ & $241.4 \pm 18.9$ & $16.3 \pm 1.6$ \\
\hline Beijing & Beijing & 9 & $193.8 \pm 33.7$ & $3.1 \pm 0.9$ & $3.4 \pm 1.1$ & $173.8 \pm 80.5$ & $34.3 \pm 7.3$ & $274.0 \pm 104.2$ & $20.2 \pm 1.1$ \\
\hline ZaoZhuang & Shandong & 9 & $249.0 \pm 92.0$ & $12.6 \pm 6.6$ & $4.4 \pm 2.4$ & $293.4 \pm 182.9$ & $21.5 \pm 3.6$ & $703.0 \pm 215.2$ & $14.4 \pm 0.8$ \\
\hline Haerbin & Heilongjiang & 9 & $335.1 \pm 90.2$ & $32.0 \pm 15.9$ & $11.7 \pm 4.2$ & $93.8 \pm 43.5$ & $13.3 \pm 11.3$ & $206.4 \pm 39.7$ & $15.1 \pm 2.4$ \\
\hline Xi'an & Shanxi & 9 & $284.6 \pm 148.3$ & $29.4 \pm 48.9$ & $8.9 \pm 2.0$ & $375.4 \pm 307.7$ & $12.6 \pm 11.5$ & $258.4 \pm 98.8$ & $16.7 \pm 3.6$ \\
\hline
\end{tabular}




\begin{tabular}{|c|c|c|c|c|c|c|c|c|c|}
\hline Guiyang & Guizhou & 9 & $234.0 \pm 105.7$ & $60.9 \pm 137.3$ & $12.2 \pm 4.8$ & $91.5 \pm 133.3$ & $11.0 \pm 6.7$ & $385.1 \pm 56.1$ & $20.0 \pm 3.6$ \\
\hline Mean & - & 210 & $253.3 \pm 142.4$ & $29.8 \pm 39.2$ & $9.2 \pm 5.8$ & $171.2 \pm 141.2$ & $23.3 \pm 29.5$ & $294.4 \pm 154.1$ & $20.1 \pm 6.3$ \\
\hline $\begin{array}{c}\text { Safety } \\
\text { standards }\end{array}$ & - & - & $5000^{\mathrm{c}, \mathrm{d}}$ & $500^{\mathrm{c}}$ & $-{ }^{e}$ & $-{ }^{e}$ & $500^{c}$ & $-{ }^{e}$ & $-{ }^{e}$ \\
\hline
\end{tabular}

${ }^{a}$ Fewer crayfish individuals were obtained due to limited sample availability.

${ }^{\mathrm{b}} \mathrm{ND}=$ not detected; individual samples that were ND were set at quantification limit $(0.15 \mu \mathrm{g} / \mathrm{kg})$ for generating means.

${ }^{\mathrm{c}}$ Referring to GB2762-2012 (SAPRC, 2012).

${ }^{\mathrm{d}}$ Assuming that $10 \%$ of As is inorganic As (Buchet et al., 1996; USFDA, 1993).

${ }^{\mathrm{e}} \mathrm{Cu}, \mathrm{Zn}, \mathrm{Ni}$ and Se were not listed in the new national standard (SAPRC, 2012). 
Table 3. Parameters used in the risk calculation.

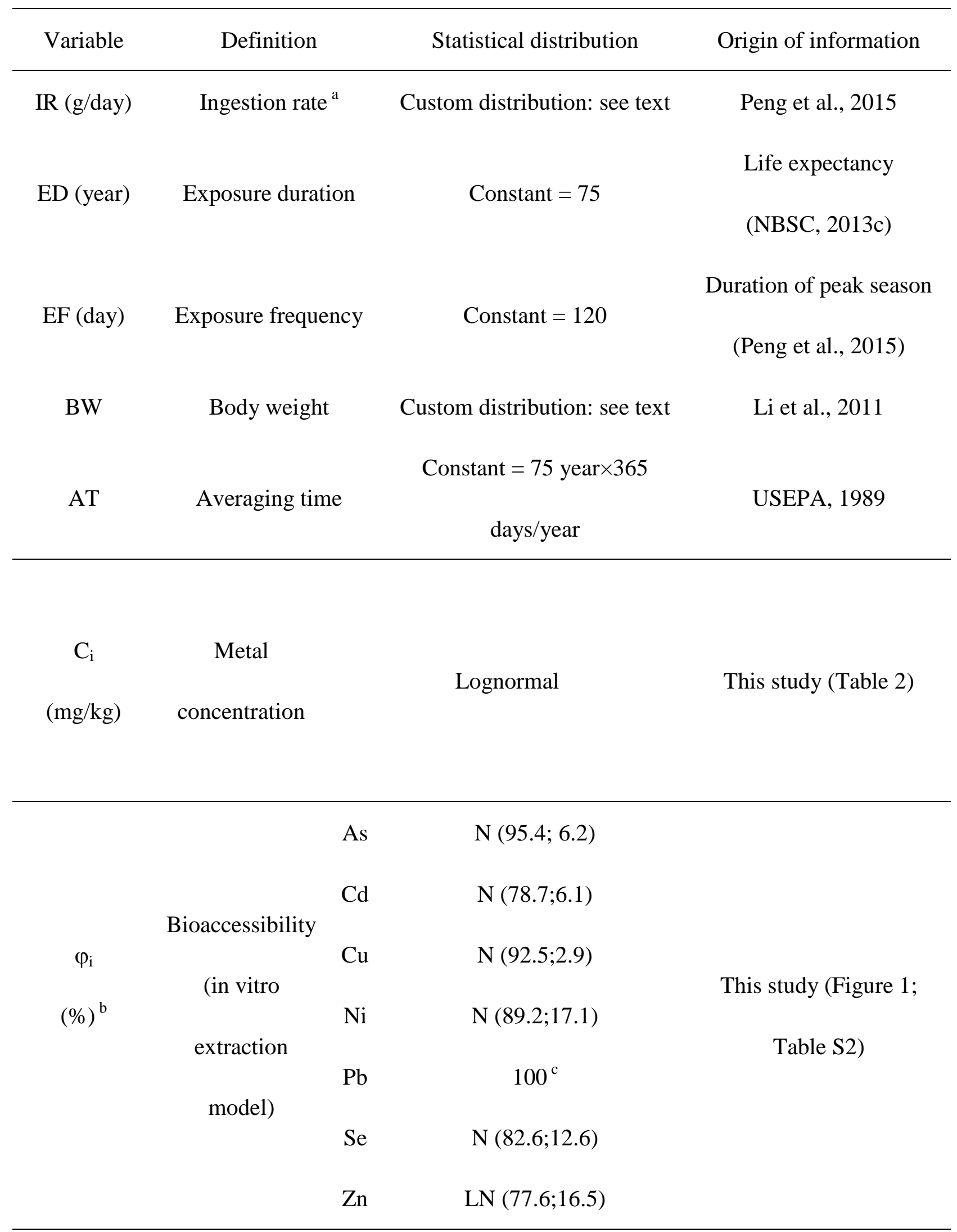

$\mathrm{N}$ : Normal distribution (mean; SD), truncated to values > 0 when needed; LN: 
Lognormal distribution (mean; SD)

${ }^{a}$ Ingestion rates were averaged and reported as daily intakes (more details in Peng et al., 2015).

${ }^{\mathrm{b}}$ Outliers were removed (more details in Table S2).

${ }^{\mathrm{c}}$ Lead bioaccessibility was not determined because extracted $\mathrm{Pb}$ levels were too low to be precisely measured. 
Table 4. Model sensitivity to input uncertainty. Contribution to variance (\%).

\begin{tabular}{ccc}
\hline & \multicolumn{2}{c}{ Risk model } \\
\cline { 2 - 3 } Parameters & $\begin{array}{c}\text { Noncancer hazard index } \\
(\mathrm{HI})\end{array}$ & $\begin{array}{c}\text { Increased lifetime cancer risk } \\
\text { (ILTR) }\end{array}$ \\
\hline IR & 95.3 & 92.5 \\
As concentration & 3.4 & 6.5 \\
$\mathrm{BW}$ woman & 0.5 & 0.4 \\
$\mathrm{BW}$ man & 0.4 & 0.4 \\
$\mathrm{Cu}$ concentration & 0.3 & - \\
$\varphi_{\mathrm{As}}$ & $<0.1$ & 0.1 \\
$\mathrm{Cd}, \mathrm{Ni}, \mathrm{Pb}, \mathrm{Se}, \mathrm{Zn}$ & $<0.1$ & - \\
concentration & $<0.1$ & \\
$\varphi_{\mathrm{Cd}}, \varphi_{\mathrm{Cu}}, \varphi_{\mathrm{Ni}}, \varphi_{\mathrm{Se}}, \varphi_{\mathrm{Zn}}$ & & \\
\hline
\end{tabular}

BW: body weight 


\section{Figure captions}

Figure 1. Element bioaccessibility $\left(\varphi_{i}\right)$ using the in vitro extraction model described by Versantvoort et al. (2005). Mean \pm standard deviation (SD).

Figure 2. Histogram of ingestion rate (IR) during peak season, based on survey results described in Peng et al. (2015). 


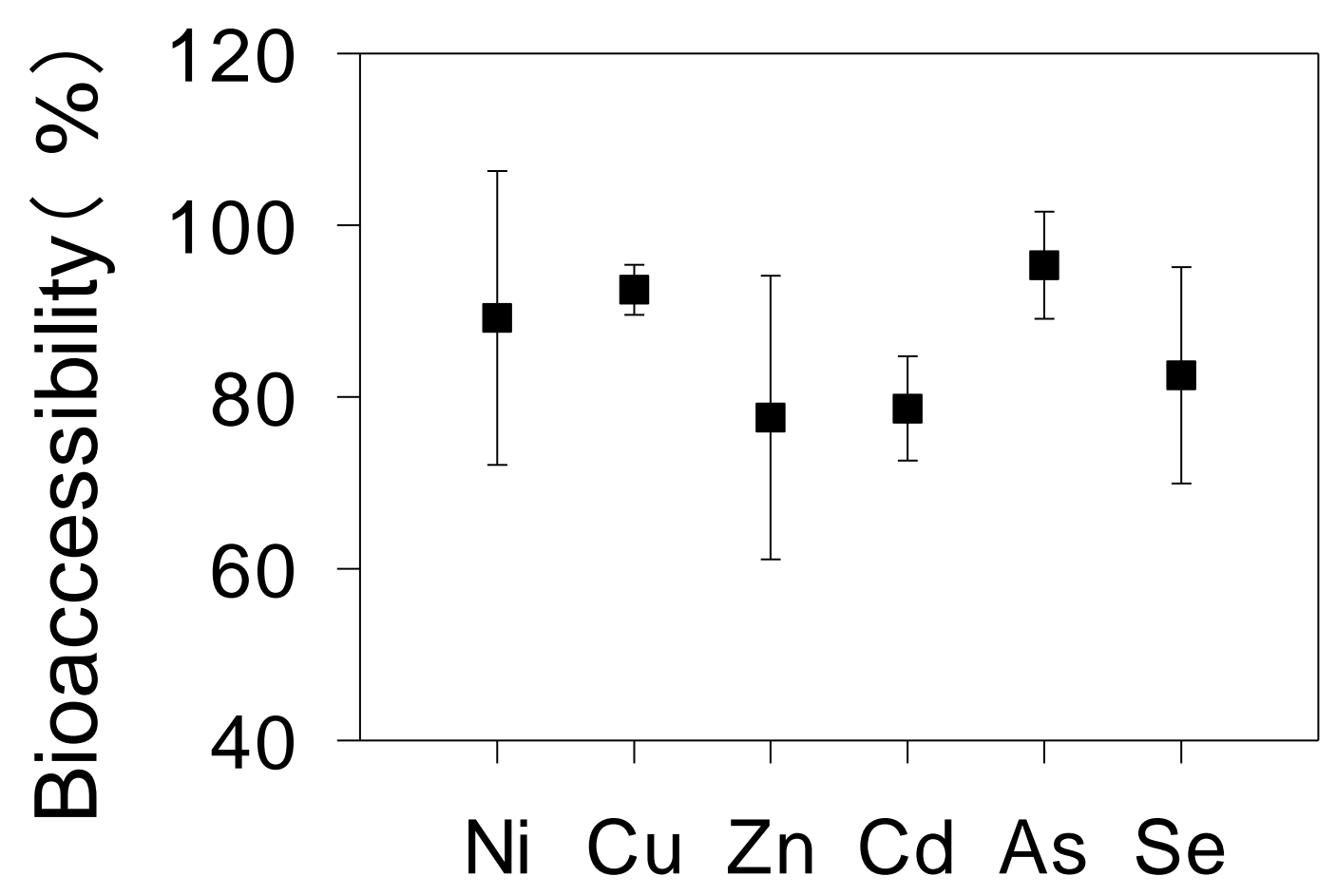

Figure 1 


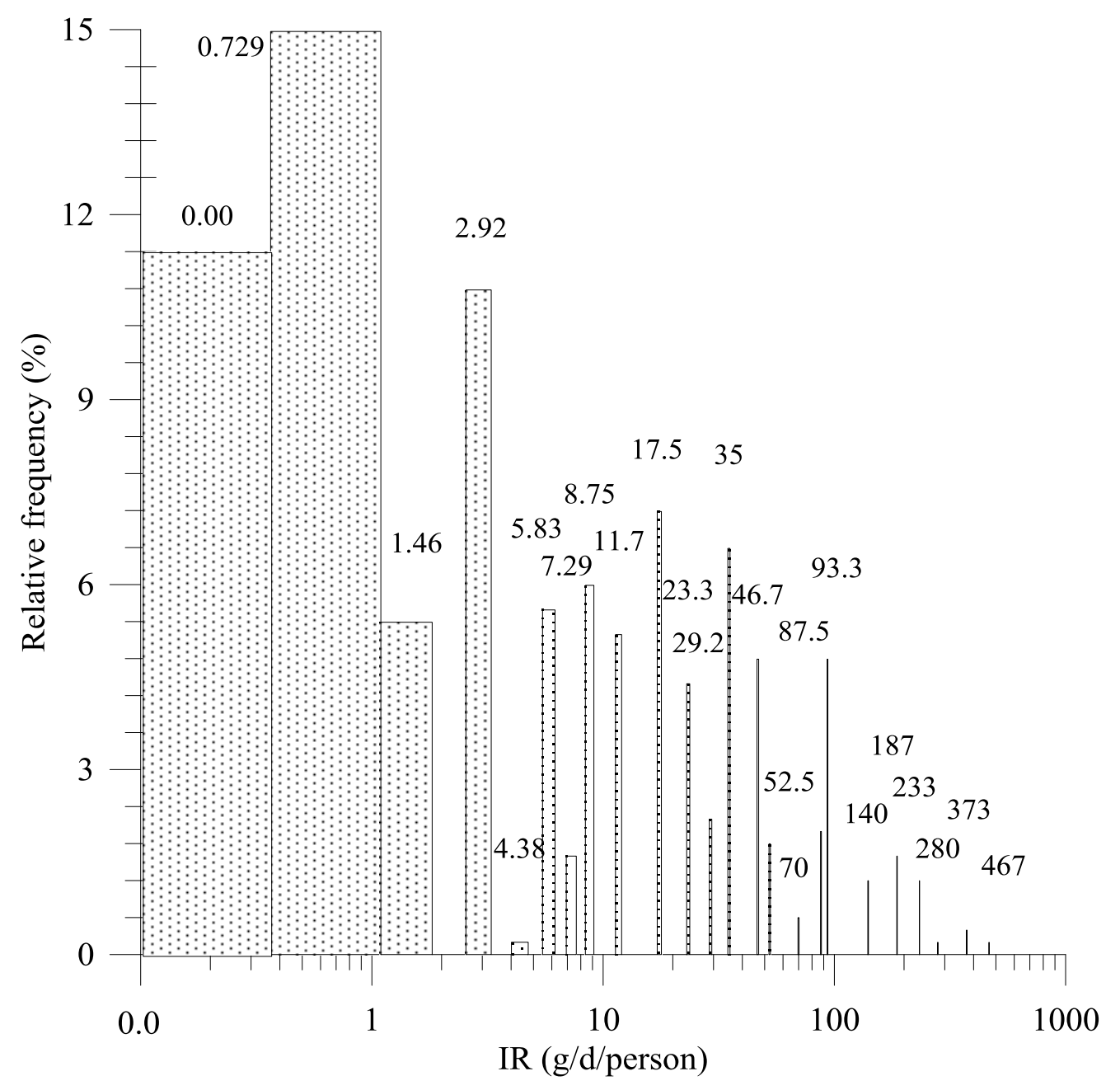

Figure 2 

exposure to metals in crayfish?

A: Arsenic poses health risk, especially for high rate consumers.

\section{$\int$ Metal concentration $(C)$ : Relatively low

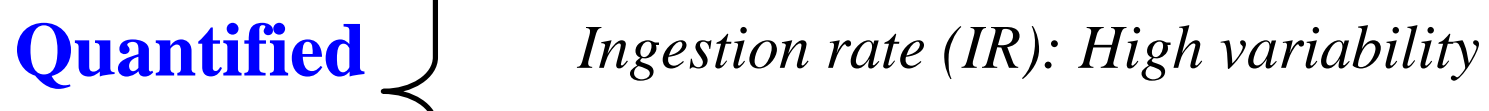 \\ parameters Bioaccessibility $(\varphi)$ : Moderate variability \\ Other parameters}

16. As

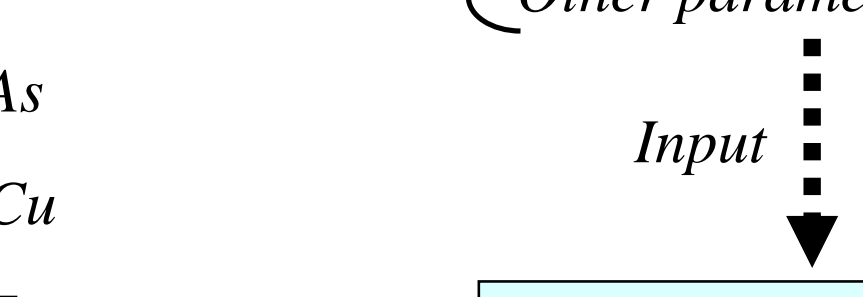

\section{$\mathrm{Zn}$}

$C d$ Risk? $\longrightarrow$

$\varphi$-modified

Risk model

$\mathrm{Pb}$

Risk assessment

Se

(1) Non-carcinogenic risk:

For high consumers $(0.5 \%)$ only

(2) Carcinogenic risk (As):

Above acceptable level for both

crayfish 